\title{
Employee Satisfaction towards Motivational Techniques of Symrise Pvt Ltd
}

\author{
Magdalene Peter, Fabiyola Kavitha
}

\begin{abstract}
This investigation features components impacting work fulfilment which thus connected with association success. The significant goal of the examination is to discover the affecting elements affecting representative activity fulfillment and furthermore to discover is there any relationship between worker work fulfillment with their assignment and work involvement with Symrise Pvt Ltd. The executives is truly keen on inspiring the representative. I put my best exertion to play out the given assignment in employment. Group pioneer/Team supervisor bolsters worker rousing variables.
\end{abstract}

Keywords: Investigation, Executives, Team Supervisor

\section{INTRODUCTION}

Motivation is a subject which enjoys a good understanding among the employers as they'll as employees, even though it is a part of day to day life in a company. There is a myth which always equates motivation with money and incentives. Of course, money might motivate to certain extent, but it is not the only motivator. Beyond incentives, employees expect more from their higher officials. The purpose of motivation is to create in which people are willing to work with real initiative, understand enthusiasm with high personal most cohesive manner[1],[3],[5]
Revised Manuscript Received on July 22, 2019.

Ms. Magdalene Peter, Department of MBA, Bharath Institute of Higher Education and Research, Chennai, India

Email: magdalene.bsb@gmail.com

Dr. Fabiyola Kavitha, Department of MBA, Bharath Institute of Higher

Education and Research, Chennai, India

Email: fabiyolakavitha@gmail.com

\section{REVIEW OF LITERATURE}

Schiffman and Kannuk(2004) define "Satisfaction,thenis the evaluation orfeeling that result from the disconfirmation process". [2],[4],[6]

Wooddruff and Gardian(1996) define " Satisfaction,thenis the evaluation orfeeling that result from the disconfirmation process."It is not the comparsion itself (ie., the disconfirmation process), but it is the customer's response to the comparsion.Satisfaction has an emotional component." [7], [9], [11]

Oliver(1997) defines"Satisfaction is the consumer's fulfilment response. It is a judgement that a product or service feature, or the product of service itself, provided (or is providing) a pleasurable level of consumption. Related

fulfilment,including levels of under-or over-fulfilment". [31], [33]

\section{OBJECTIVES}

- To know the impact of employee ssatisfaction towards motivational techniques.

- To analyse the need of the employees.

- To retain value and productive employees.

- To promote specific job behaviors conductive to higher levels of job performance. [8], [10],[12]

\section{RESEARCH METHODOLOGY}

\section{A. Research design}

The research method used is of descriptive method. Descriptive research is used to define research problem and gathering information related to the problems for carrying out research. [13], [15],[17]

[a] Primary data:

The source of primary data was a structured questionnaire. By structured questionnaire method, the primary data was collected from the employees of Symrise Pvt ltd Company.

[b] Secondary data:

Secondary data are those which have been already collected and analyzed by some earlier agency for its own use; and later the same data are used by a different agency. The secondary data was gathered from the magazines and websites. [14], [16],[18]

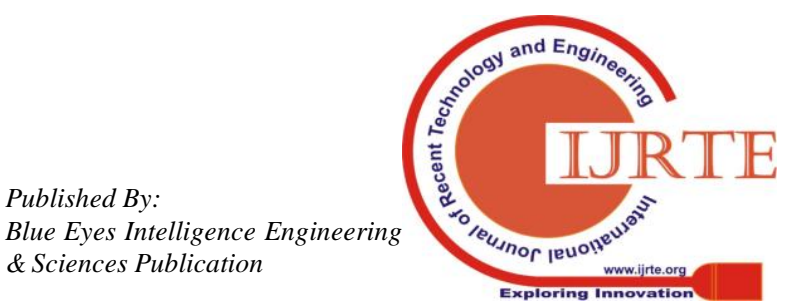




\section{V.RESULTS AND DISCUSSIONS}

- 58\% of respondents are between the age group 20-30

- $62 \%$ of respondents income level is below 5000

- $48 \%$ of respondents work experience is of 0-5 years

- $58 \%$ of respondents are in executive level [19], [21],[23]

- $62 \%$ of respondents are motivated by monetary factor

- $35 \%$ of respondents shows the rating 1 for incentives

- $35 \%$ of respondents shows the rating 1 for salary increase

- $32 \%$ of respondents shows the rating 1 for promotion

- $30 \%$ of respondents shows the rating 3 for bonus

- $37 \%$ of respondents shows the rating for appreciation \& recognition

- $37 \%$ of respondents shows the rating 1 for work condition [20], [22], [24]

- $37 \%$ of respondents shows the rating 1 for job security

- $30 \%$ of respondents shows the rating 2 for job security

- $45 \%$ of respondents strongly agree that management is interested in employee motivation[25], [27], [29]

\section{CONCLUSION}

SymrisePvt. Ltd is a fragrance producing organization. The Symrise group was formed in 2003 by a merger between the German companies Haarmann\& Reimer and Dragoco. The Symrise Company is now famous in our country due to his quality in making fragrance; Symrise Company is also famous to their price satisfaction towards customers Employee motivation towards the Symrise organization. [26], [28], [30]

\section{REFERENCES}

1) BharthVajan R., Ramachandran S.,Psychographic dimensions of training,2016,International Journal of Pharmacy and Technology,V-8,I-4,P-23727-23729

2) Balakrishnan P., Bharthvajan R.,A study on human resource planning in hospitals in Chennai City,2014,International Journal of Applied Engineering Research,V-9,I-22,P-7503-7507

3) Priyadarsini P., Bharthvajan R.,Role of emotional intelligence training programme in reducing the stress of the nurses,2014,International Journal of Applied Engineering Research,V-9,I-22,P-7411-7421

4) Kerinab Beenu G., Bharthvajan R.,Empirical analysis on the cosmetic buying behavior of young women in South India,2014,International Journal of Applied Engineering Research,V-9,I-22,P-7361-7366

5) Balakrishnan P., Bharthvajan R.,Whistling in the wind,2014,International Journal of Applied Engineering Research,V-9,I-22,P-7586-7593

6) Krishnan B., Peter M.,Health hazards of Indian Bpo employee-an alarming issue,2014,International Journal of Applied Engineering Research,V-9,I-22,P-7336-7341

7) Kerinab Beenu G.H., Peter M.,Role of insurance in economic development,2014,International Journal of Applied Engineering Research,V-9,I-22,P-7532-7539

8) Balakrishnan P., Peter M., Priyadarsini P.,Efficiency of safety measures for wellbeing of employees in manufacturing industry,2014,International Journal of Applied Engineering Research,V-9,I-22,P-7376-7382

9) Anbarasi M., Praveen Kumar S.,Online sales promotions of herbal products and its effectiveness towards tanisha.com,2019,Indian Journal of Public Health Research and Development,V-10,I-1,P-195-200

10) Anbarasi M., Praveen Kumar S., Various online marketing and promotions strategies to improve the validation towards the organic products in the pharmaceutical sectors,2019,Indian Journal of Public Health Research and Development,V-10,I-1,P-263-269

11) Loganathan R., Praveen Kumar S.,Grievance handling a key factor for solving issues of employees in an organization,2014,International Journal of Applied Engineering Research,V-9,I-22,P-7483-7491

12) Loganathan R., Praveen Kumar S.,Study on preference of private label brands in super and Hypermarkets,2014,International Journal of Applied Engineering Research,V-9,I-22,P-7327-7335
13) Smitha M., Praveen Kumar S.,Understanding stress and its managementamong the nurses in Chennai city,2014,International Journal of Applied Engineering Research,V-9,I-22,P-7560-7565

14) Kerinab Beenu G.H., Praveen Kumar S.,A study on the investment behavior of Chennai investors in mutual fund schemes,2014,International Journal of Applied Engineering Research,V-9,I-22,P-7520-7525

15) Loganathan R., Praveen Kumar S.,Retention strategies key for organizational productivity,2014,International Journal of Applied Engineering Research,V-9,I-22,P-7443-7447

16) Pavithra J., Ganesan M., Brindha G.,State wise analysis of microfinance sector in India,2016,International Journal of Pharmacy and Technology,V-8,I-4,P-23417-23432

17) Pavithra J., Ganesan M.,A comparative study on microfinance in India and abroad,2016,International Journal of Applied Business and Economic Research,V-14,I-8,P-5471-5476

18) Pavithra J., Ganesan M.,A study on awareness and impact of micro-financial schemes, 2016,International Journal of Applied Business and Economic Research,V-14,I-8,P-5449-5460

19) Senthilmurugan P., Pavithra J.,Consumer preference towards organised retailing with reference to Big Bazaar,2014,International Journal of Applied Engineering Research,V-9,I-22,P-7469-7475

20) Senthilmurugan P., Pavithra J.,Implication of social media marketing in growing healthcare industry,2014,International Journal of Applied Engineering Research,V-9,I-22,P-7448-7456

21) Loganathan R., Pavithra J.,Consumer perception towards private label brand over other brands in super markets and hypermarkets,2014,International Journal of Applied Engineering Research,V-9,I-22,P-7355-7360

22) Kerinab Beenu G., Pavithra J.,Tradeâ€“off between liquidity and profitability in logistics industry,2014,International Journal of Applied Engineering Research,V-9,I-22,P-7398-7401

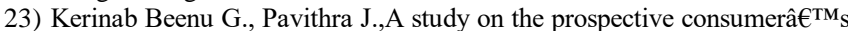
perception towards utility cars in Chennai city,2014,International Journal of Applied Engineering Research,V-9,I-22,P-7526-7531

24) Pavithra J., Dilli Babu P., Ambuli T.V.,A study on budgetary control at Maruti Service Masters, Chennai,2014,International Journal of Applied Business and Economic Research,V-12,I-2,P-151-161

25) Pavithra J., Dilli Babu P., Ambuli T.V.,A study on customer satisfaction of retro Garments Pvt Ltd, Chennai,2014,International Journal of Applied Business and Economic Research,V-12,I-2,P-381-391

26) Kerinab Beenu G.H., Pavithra J., Senthilmurugan P.,A study on the influence of promotional activities for TATA ARIA among consumers in Chennai,2014,International Journal of Applied Engineering Research,V-9,I-22,P-7572-7578

27) Vijayaragavan S.P.,An investigative expert that's general FBG sensors,International Journal of Mechanical Engineering and Technology,V-8,I-8,PP-1500-1505,Y-2017

28) Vijayaragavan S.P.,Equalization routing protocol for Wi-Fi sensor strategy,International Journal of Mechanical Engineering and Technology,V-8,I-8,PP-1662-1666,Y-2017

29) Karthik B., Kiran Kumar T.V.U., Vijayaragavan P., Bharath Kumaran E.,Design of a digital PLL using 0.35 $\hat{\mathrm{I}}^{1 / 4 \mathrm{~m}} \mathrm{CMOS}$ technology,Middle East Journal of Scientific Research,V-18,I-12,PP-1803-1806,Y-2013

30) Kanniga E., Selvaramarathnam K., Sundararajan M.,Kandigital bike operating system,Middle - East Journal of Scientific Research,V

31) Jasmin M., Vigneshwaran T., Beulah Hemalatha S.,Design of power aware on chip embedded memory based FSM encoding in FPGA,International Journal of Applied Engineering Research,V-10,I-2,PP-4487-4496,Y-2015

32) Jasmin M.,Optimization techniques for low power VLSI circuits,Middle East Journal of Scientific Research,V-20,I-9,PP-1082-1087,Y-2014

33) Jasmin M., Vigneswaran T.,Fuzzy controller for error control of on - Chip communication,2017 International Conference on Algorithms, Methodology, Models and Applications in Emerging Technologies, ICAMMAET 2017,V-2017-January,I-,PP-1-5,Y-2017

\section{AUTHORS PROFILE}

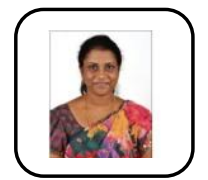

Ms. Magdalene Peter Assistant Professor, Department of MBA, Bharath Institute of Higher Education and Research, Chennai, India.

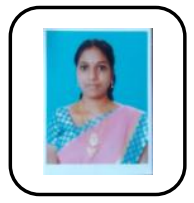

Dr. Fabiyola Kavitha Associate Professor, Department of MBA, Bharath Institute of Higher Education and Research, Chennai, India. 